\title{
KAJIAN PERBAIKAN POSTUR KERJA DENGAN METODE OWAS (OVAKO WORKING POSTURE ANALYSIS SYSTEM) (Studi Kasus di Pabrik Roti Cimpago Putih)
}

\author{
Meldia Fitri ${ }^{1}$, Widya Laila $^{2}$, Fendi $^{3}$ \\ Program Studi Teknik Industri, Sekolah Tinggi Teknologi Industri Padang \\ email : meldia.ananda@yahoo.com
}

\begin{abstract}
ABSTRAK
The roles of human as workers are still dominant in conducting production process, especially that related to manual activities. One of the humans rote is in the procss of displacing materials. These activities potentially raise various camplaints such as muscle pain and could cause accident at work. Pabrik Roti Cimpago Whit Bread still conduct MMH (Manual Materials Handling) activites in producing bread. These make the workers get low back pain. Theis research seeks to identify and evaluate inappropriate body posture at work and recommend safe body posture for the workers by using OWAS (Ovako Working Posture Analysis System). Analysis syetem through which 7 working posture were corrected of the 7, 4 posture were classified into category 2 suggerting that they were dangerous for musculoskeletal sytem and 3 postures were classified into category 3 indicating that they were unsafe for musculoskeletal and needed immediate repair.
\end{abstract}

Keywords: work posture, OWAS, improvement work posture.

\section{PENDAHULUAN}

Pemindahan material secara manual menimbulkan kecelakaan kerja yaitu cidera pada tulang belakang, sedangkan dari sudut pandang fisiologi Manual Material Handling (MMH) atau pemindahan material secara manual membutuhkan energi yang cukup besar. Tetapi pemindahan bahan secara manual apabila tidak dilakukan secara ergonomis akan menimbulkan kecelakaan dalam industri, (Nurmianto, 1996).

Aktivitas membungkuk dan memutar didalam tempat kerja saat melakukan Manual Material Handling seharusnya dikurangi atau sebaiknya dihilangkan karena sikap ini dapat menimbulkan gangguan pada sistem musculoskeletal. Keluhan musculoskeletal adalah keluhan pada bagian-bagian otot skeletal yang dirasakan oleh seseorang mulai dari keluhan ringan sampai sangat sakit. Apabila seseorang menerima beban statis secara berulang dan dalam waktu yang lama akan dapat menyebabkan keluhan berupa kerusakan pada sendi, ligamen dan tendon. Keluhan hingga kerusakan inilah yang biasanya diistilahkan dengan keluhan musculoskeletal disorders (MSDs) atau cidera pada sistem musculoskeletal (Granjen, 1993 dan Lamasters, 1996, keduanya dalam Purwaningsih dkk, 2006).

Salah satu prinsip perancangan sistem kerja dalam aktivitas MMH adalah menjaga posisi pinggul dan bahu lurus atau segaris ketika melakukan aktivitas MMH (Alexander, 1986). Hal ini untuk menjaga pembebanan pada punggung tetap sedikit, karena jarak antar pusat beban dengan tubuh dekat sehingga momen dihasilkan relatif kecil.

Pabrik Roti Cimpago putih adalah perusahan yang bergerak di bidang pembuatan roti dimana ada 3 rasa roti yang dihasilkan seperti rasa coklat, keju dan kelapa. Dimana proses pembuatan roti terdiri atas penimbangan bahan di stasiun penimbangan, bahan yang sudah ditimbang tersebut dicampur dengan 
tepung di stasiun pengadukan, setelah tepung di aduk akan di haluskan di stasiun press, setelah tepung di haluskan maka dilakukan pencetakan di stasiun pencetakan, dan setelah tepung dicetak maka dilakukan fermentasi di stasiun fermentasi, ditahap fermentasi waktu yang dibutuhkan adalah 3 jam, setelah di fermentasi roti di bakar di oven selama 5 menit, setelah roti dibakar dilakukan pengemasan.

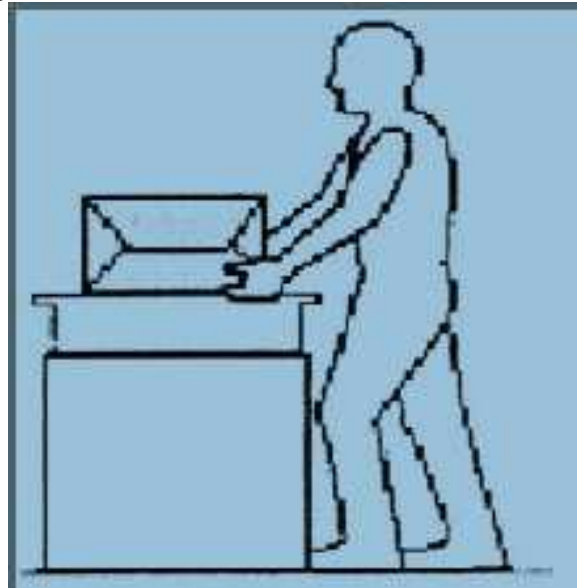

Gambar 1. Sikap kerja

Pabrik Roti Cimpago Putih memiliki 2 orang pekerja untuk memproduksi roti, tinggi badan 165 dan $170 \mathrm{~cm}$ berjenis kelamin laki laki. Pabrik Roti Cimpago Putih melakukan pekerjaan pemindahan loyang sebanyak 600 sekali produksi dan setiap loyang memiliki ukuran panjang 30 $\mathrm{cm}$, lebar $32 \mathrm{~cm}$ dan tinggi $3 \mathrm{~cm}$. seperti gambar 1.1 di bawah ini :

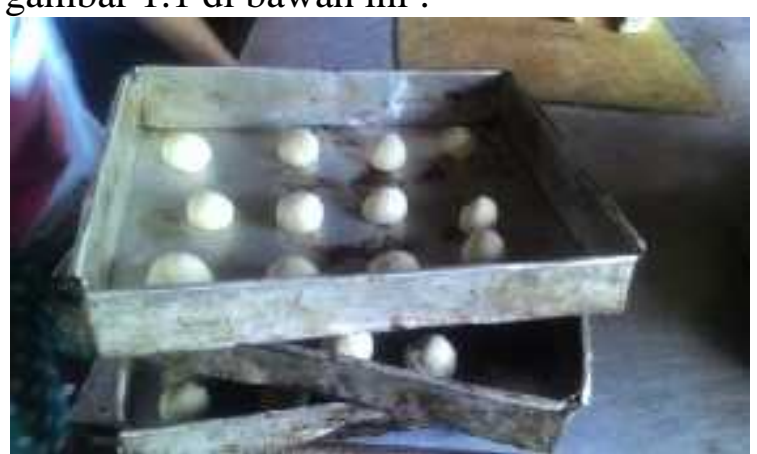

Gambar 2. Loyang.

Pemindahan loyang di Pabrik Roti Cimpago Putih masih dilakukan secara manual sehingga aktivitas pekerjaan pemindahan loyang selalu melakukan gerakan pengulangan dan terdapat postur tubuh membungkuk pada saat mengangkat loyang.
Selain pemindahan loyang yang menimbulkan kesulitan pekerja juga mengalami keluhan rasa sakit pada beberapa bagian tubuh yang dibuktikan melalui Ovako Working Posture Analysis System (OWAS). merupakan suatu metode untuk mengevaluasi dan menganalisa sikap kerja yang tidak nyaman dan berakibat pada cidera musculoskeletal (Karhu dkk, 1981). Bagian sikap kerja dari pekerja yang diamati meliputi pergerakan tubuh dari bagian punggung, bahu, tangan, dan kaki (termasuk paha, lutut, pergelangan kaki).

\section{METODOLOGI PENELITIAN}

Jenis penelitian yang dilakukan penulis adalah penelitian deskriptif kuantitatif yaitu pengolahan data yang berupa angka pada suatu perusahaan atau industri yang nantinya data akan dikumpulkan dan diolah sehingga memberikan informasi yang berguna dengan menggunakan perumusan matematika. Tujuan dari penelitian deskriptif ini adalah untuk membuat deskripsi, gambaran atau lukisan secara sistematis, faktual dan akurat mengenai fakta-fakta, sifat-sifat serta hubungan antar fenomena yang diselidiki (Nazir, 2005).

\subsection{Metode Analisis Postur Kerja OWAS}

Proses Coding Postures adalah proses menterjemahkan postur kerja dari hasil perekaman sesuai dengan postur kerja menurut kode empat digit. Kode tersebut meliputi postur tubuh bagian punggung, lengan, kaki dan berat beban. Berikut kode postur kerja menurut metode OWAS.

A. Sikap Punggung

1. Lurus

2. Membungkuk

3. Memutar atau miring kesamping

4. Membungkuk dan memutar atau membungkuk kedepan dan menyamping 

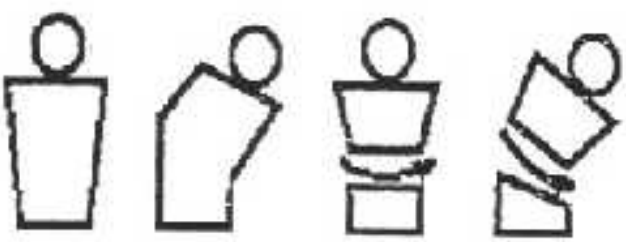

1
3
D. Berat Beban

1. Berat beban adalah kurang dari 10 $\mathrm{Kg}(\mathrm{W}=10 \mathrm{Kg})$

2. Berat beban adalah $10 \mathrm{Kg}-20 \mathrm{Kg}$ $(10 \mathrm{Kg}<\mathrm{W}=20 \mathrm{Kg})$

3. Berat beban adalah lebih besar dari $20 \mathrm{Kg}(\mathrm{W}>20 \mathrm{Kg})$

Hasil dari analisa postur kerja OWAS terdiri dari empat level skala sikap kerja yang berbahaya bagi para pekerja.

KATEGORI 1 : Pada sikap ini tidak ada masalah pada system muskuloskeletal (tidak berbahaya). Tidak perlu ada perbaikan.

KATEGORI 2 : Pada sikap ini berbahaya pada sistem
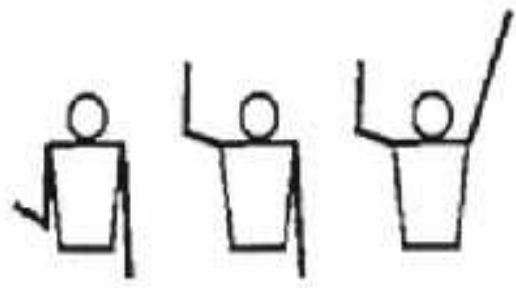

1

2

3
Gambar 4. Klasifikasi sikap kerja bagian lengan

C. Sikap Kaki

1. Duduk

2. Berdiri bertumpu pada kedua kaki lurus

3. Berdiri bertumpu pada satu kaki lurus

4. Berdiri bertumpu pada kedua kaki dengan lutut ditekuk

5. Berdiri bertumpu pada satu kaki dengan lutut ditekuk

6. Berlutut pada satu atau kedua lutut

7. Berajalan

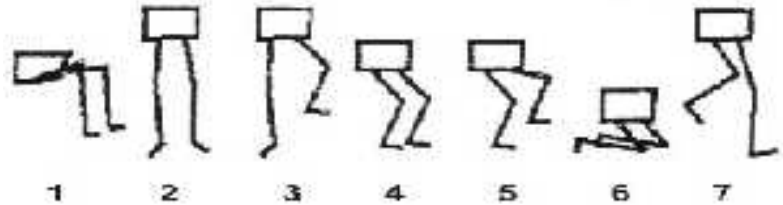

Gambar 5. Klasifikasi sikap kerja bagian kaki musculoskeletal (postur kerja mengakibatkan pengaruh ketegangan yang signifikan). Perlu perbaikan dimasa yang akan datang.

KATEGORI 3 : Pada sikap ini berbahaya pada sistem musculoskeletal (postur kerja mengakibatkan pengaruh ketegangan yang sangat signifikan). Perlu perbaikan segera mungkin.

KATEGORI 4 : Pada sikap ini sangat berbahaya pada system muskuloskeletal (postur kerja ini mengakibatkan resiko yang jelas). Perlu perbaikan secara langsung / saat ini juga.

Berikut ini merupakan tabel kategori tindakan kerja OWAS secara keseluruhan, berdasarkan kombinasi klasifikasi sikap dari punggung, lengan, kaki dan berat beban. 
Tabel 2. Kategori tindakan kerja OWAS

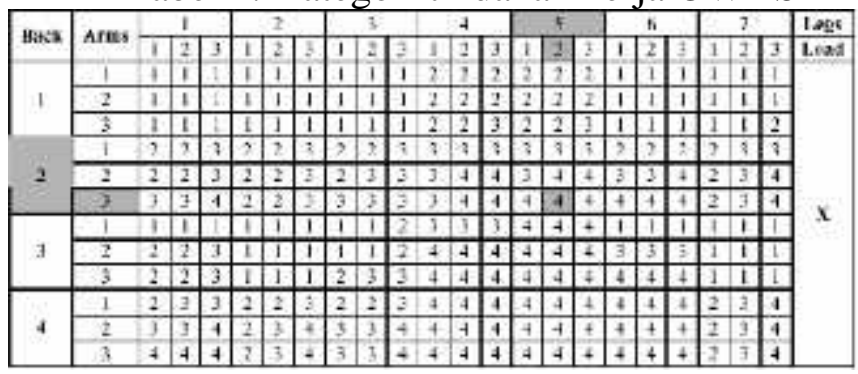

Tabel diatas menjelaskan mengenai klasifikasi postur-postur kerja ke dalam kategori tindakan. Sebagai contoh postur kerja dengan kode 2352, maka postur kerja ini merupakan postur kerja dengan kategori tindakan dengan derajat perbaikan level 4, yaitu pada sikap ini berbahaya bagi sistem musculoskeletal (sikap kerja ini mengakibatkan resiko yang jelas). Perlu perbaikan secara langsung atau saat ini.

\section{PENGOLAHAN DATA}

\subsection{Penentuan Jarak Antar Fasilitas Produksi Layout Awal}

Penentuan frekuensi perpindahan antar stasiun kerja adalah berapa jumlah satuan/ unit yang dapat dipindahkan dalam sekali perpindahan serta perpindahan tersebut berapa kali dilakukan dalam satuan waktu (bulan).Jarak suatu area aktivitas satu dengan area aktivitas yang lain dapat ditentukan, penentuan jarak perpindahannya dengan menggunakan sistem jarak euclidean. Masing - masing area aktifitas dicari titik pusatnya yaitu (0.0) dari $\mathrm{x}$ dan $\mathrm{y}$. Pada lay out awal diketahui bahwa titik pusat untuk gudang bahan baku yaitu $(4,5 ; 7)$ dan titik pusat untuk stasiun perendaman pada tungku 1 yaitu $(0,5 ; 5,1)$. Jadi jarak perpindahan dari gudang bahan baku dengan stasiun perendaman pada tungku 1 adalah sebagai berikut :

$$
\begin{aligned}
\text { Jarak } & =\sqrt{\left[\left(x_{i}-x_{j}\right)^{2}+\left(y_{i}-y_{j}\right)^{2}\right]} \\
& =\sqrt{\left[(4,5-0,5)^{2}+(7-5,1)^{2}\right]} \\
& =4,4 \text { meter }
\end{aligned}
$$

Dari hasil pengolahan data yang dilakukan dengan sistem jarak euclidean masih terdapat jarak perpindahan antar masing-masing stasiun kerja yang cukup jauh dan dapat mengakibatkan biaya perpindahan yang makin besar.

\subsection{Penentuan Performansi Lay Out Awal}

Ongkos material handling untuk setiap kali pengangkutan ditentukan berdasarkan ongkos permeter gerakan. Dalam mencari layout awal terlebih dahulu kita tentukan jarak dikali dengan frekuensi perbulan.

Setelah itu lalu mencari gaji seorang pekerja permenit yaitu sebesar Rp 133,3/menit. Setelah didapatkan gaji pekerja permenit, langkah selanjutnya adalah mencari $\mathrm{OMH}$ permeter gerakan dengan cara mengalikan waktu perpindahan permenit dikali dengan gaji pekerja permenit dan frekuensi setiap kali melakukan proses pemindahan. Total dari $\mathrm{OMH}$ yang didapat dibagi dengan total jarak dikali frekuensi dan didapatlah hasil OMH per meter gerakan yaitu Rp 358,3. Setelah itu barulah didapat $\mathrm{OMH}$ untuk semua stasiun kerja sebesar Rp 105.692.230 ongkos yang didapat lumayan besar dan diharapkan bisa diturunkan menjadi lebih kecil dari sekarang.

\subsection{Proses Coding Postures Rekaman Postur kerja}

Proses Coding Postures adalah proses menterjemahkan postur kerja dari hasil perekaman sesuai dengan postur kerja menurut kode empat digit. Kode tersebut meliputi postur tubuh bagian punggung, lengan, kaki dan berat beban.

1. Stasiun Penimbangan

Pada stasiun ini dilakukan penimbangan bahan seperti gula, garam, keju, dan bahan lain lain nya.

Tabel 3. OWAS Stasiun Penimbangan

\begin{tabular}{|l|l|l|}
\hline \multicolumn{1}{|c|}{ SIKAP } & KODE & \multicolumn{1}{c|}{ KETERANGAN } \\
\hline Punggung & 1 & Lurus \\
\hline Lengan & 1 & $\begin{array}{l}\text { Kedua lengan berada } \\
\text { di bawah bahu }\end{array}$ \\
\hline Kaki & 2 & $\begin{array}{l}\text { Berdiri bertumpu } \\
\text { pada kedua kaki }\end{array}$ \\
\hline
\end{tabular}




\begin{tabular}{|l|l|l|}
\hline & & lurus \\
\hline $\begin{array}{l}\text { Berat } \\
\text { beban }\end{array}$ & 1 & $\begin{array}{l}\text { Berat beban lebih } \\
\text { kecil atau sama } \\
\text { dengan } 10 \mathrm{Kg} .\end{array}$ \\
\hline
\end{tabular}

2. Stasiun Pengadukan

Pada stasiun ini pekerja melakukan pengadukan tepung dengan bahan bahan.

Tabel 4. OWAS Stasiun pengadukan

\begin{tabular}{|l|l|l|}
\hline \multicolumn{1}{|c|}{ SIKAP } & KODE & \multicolumn{1}{|c|}{ KETERANGAN } \\
\hline Punggung & 2 & $\begin{array}{l}\text { Bungkuk kedepan } \\
\text { atau kebelakang }\end{array}$ \\
\hline Lengan & 1 & $\begin{array}{l}\text { Kedua lengan berada } \\
\text { di bawah bahu }\end{array}$ \\
\hline Kaki & 4 & $\begin{array}{l}\text { Berdiri bertumpu } \\
\text { pada kedua kaki } \\
\text { dengan posisi kedua } \\
\text { lutut ditekuk }\end{array}$ \\
\hline $\begin{array}{l}\text { Berat } \\
\text { beban }\end{array}$ & 1 & $\begin{array}{l}\text { Berat beban lebih } \\
\text { kecil atau sama } \\
\text { dengan } 10 \mathrm{Kg} .\end{array}$ \\
\hline
\end{tabular}

3. Stasiun Press

Pada stasiun press ini pekerja melakukan penghalusan tepung lebih halus lagi dengan mengunakan mesin.

Tabel 5. OWAS Stasiun Press

\begin{tabular}{|l|l|l|}
\hline \multicolumn{1}{|c|}{ SIKAP } & KODE & KETERANGAN \\
\hline Punggung & 1 & Lurus \\
\hline Lengan & 3 & $\begin{array}{l}\text { Kedua lengan } \\
\text { berada pada atau } \\
\text { di atas bahu }\end{array}$ \\
\hline Kaki & 2 & $\begin{array}{l}\text { Berdiri bertumpu } \\
\text { pada kedua kaki } \\
\text { lurus }\end{array}$ \\
\hline Berat beban & 1 & $\begin{array}{l}\text { Berat beban lebih } \\
\text { kecil atau sama } \\
\text { dengan } 10 \mathrm{Kg} .\end{array}$ \\
\hline
\end{tabular}

4. Stasiun pencetakan

Pada stasiun pencetakan pekerja melakukan pementukan adonan roti berupa bulat.
Tabel 6. Stasiun Pencetakan

\begin{tabular}{|l|l|l|}
\hline \multicolumn{1}{|c|}{ SIKAP } & KODE & \multicolumn{1}{|c|}{ KETERANGAN } \\
\hline Punggung & 1 & Lurus \\
\hline Lengan & 1 & $\begin{array}{l}\text { Kedua lengan berada di } \\
\text { bawah bahu }\end{array}$ \\
\hline Kaki & 2 & $\begin{array}{l}\text { Berdiri bertumpu pada } \\
\text { kedua kaki lurus }\end{array}$ \\
\hline $\begin{array}{l}\text { Berat } \\
\text { beban }\end{array}$ & 1 & $\begin{array}{l}\text { Berat beban lebih kecil } \\
\text { atau sama dengan } 10 \mathrm{Kg} .\end{array}$ \\
\hline
\end{tabular}

5. Stasiun Fermentasi

a. Pada stasiun fermentasi ini pekerja melakukan pengangkatan loyang.

Tabel 7. OWAS Stasiun Fermentasi Postur 1

\begin{tabular}{|l|l|l|}
\hline \multicolumn{1}{|c|}{ SIKAP } & KODE & \multicolumn{1}{|c|}{ KETERANGAN } \\
\hline Punggung & 2 & $\begin{array}{l}\text { Bungkuk kedepan atau } \\
\text { kebelakang }\end{array}$ \\
\hline Lengan & 1 & $\begin{array}{l}\text { Kedua lengan berada di } \\
\text { bawah bahu }\end{array}$ \\
\hline Kaki & 2 & $\begin{array}{l}\text { Berdiri bertumpu pada } \\
\text { kedua kaki lurus }\end{array}$ \\
\hline $\begin{array}{l}\text { Berat } \\
\text { beban }\end{array}$ & 1 & $\begin{array}{l}\text { Berat beban lebih kecil } \\
\text { atau sama dengan } 10 \mathrm{Kg} .\end{array}$ \\
\hline
\end{tabular}

b. Setelah loyang di angkat maka pekerja berdiri dan bersiap untuk berjalan ke fermentasi.

Tabel 8. OWAS Stasiun Fermentasi

Postur 2

\begin{tabular}{|l|l|l|}
\hline \multicolumn{1}{|c|}{ SIKAP } & KODE & \multicolumn{2}{|c|}{ KETERANGAN } \\
\hline Punggung & 4 & $\begin{array}{l}\text { Bungkuk dan } \\
\text { memutar atau } \\
\text { bungkuk kedepan } \\
\text { dan menyamping }\end{array}$ \\
\hline Lengan & 1 & $\begin{array}{l}\text { Kedua lengan berada } \\
\text { di bawah bahu }\end{array}$ \\
\hline Kaki & 7 & Berjalan \\
\hline $\begin{array}{l}\text { Berat } \\
\text { beban }\end{array}$ & 1 & $\begin{array}{l}\text { Berat beban lebih } \\
\text { kecil atau sama } \\
\text { dengan 10 Kg. }\end{array}$ \\
\hline
\end{tabular}

c. Pekerja berjalan menuju tempat fermentasi maka loyang di letakan di stasiun fermentasi. 
Tabel 9. OWAS Stasiun Fermentasi Postur 3

\begin{tabular}{|l|l|l|}
\hline \multicolumn{1}{|c|}{ SIKAP } & KODE & \multicolumn{1}{|c|}{ KETERANGAN } \\
\hline Punggung & 2 & $\begin{array}{l}\text { Bungkuk kedepan } \\
\text { atau kebelakang }\end{array}$ \\
\hline Lengan & 1 & $\begin{array}{l}\text { Kedua lengan berada } \\
\text { di bawah bahu }\end{array}$ \\
\hline Kaki & 4 & $\begin{array}{l}\text { Berdiri bertumpu } \\
\text { pada kedua kaki } \\
\text { dengan posisi kedua } \\
\text { lutut ditekuk }\end{array}$ \\
\hline $\begin{array}{l}\text { Berat } \\
\text { beban }\end{array}$ & 1 & $\begin{array}{l}\text { Berat beban lebih } \\
\text { kecil atau sama } \\
\text { dengan 10 Kg. }\end{array}$ \\
\hline
\end{tabular}

\section{Stasiun Oven}

a. pekerja melakukan pemanggangan roti dimana pekerja melakukan postur kerja mengangkat loyang ke oven

Tabel 10. OWAS Stasiun Oven Postur 1

\begin{tabular}{|l|l|l|}
\hline \multicolumn{1}{|c|}{ SIKAP } & KODE & \multicolumn{1}{|c|}{ KETERANGAN } \\
\hline Punggung & 2 & $\begin{array}{l}\text { Bungkuk kedepan } \\
\text { atau kebelakang }\end{array}$ \\
\hline Lengan & 1 & $\begin{array}{l}\text { Kedua lengan berada } \\
\text { di bawah }\end{array}$ \\
\hline Kaki & 4 & $\begin{array}{l}\text { Berdiri bertumpu } \\
\text { pada kedua kaki } \\
\text { dengan posisi kedua } \\
\text { lutut ditekuk }\end{array}$ \\
\hline $\begin{array}{l}\text { Berat } \\
\text { beban }\end{array}$ & 1 & $\begin{array}{l}\text { Berat beban lebih } \\
\text { kecil atau sama } \\
\text { dengan } 10 \mathrm{Kg} .\end{array}$ \\
\hline
\end{tabular}

b. Pekerja melakukan pemanggangan roti dimana loyang dimasukan ke dalam oven

Tabel 11. Perbaikan Postur Kerja yang Berbahaya Pada Aktivitas Pembuatan Roti OWAS Stasiun Oven Postur 2

\begin{tabular}{|l|l|l|}
\hline \multicolumn{1}{|c|}{ SIKAP } & KODE & \multicolumn{1}{|c|}{ KETERANGAN } \\
\hline Punggung & 2 & $\begin{array}{l}\text { Bungkuk kedepan } \\
\text { atau kebelakang }\end{array}$ \\
\hline Lengan & 1 & $\begin{array}{l}\text { Kedua lengan berada } \\
\text { di bawah bahu }\end{array}$ \\
\hline Kaki & 2 & Berdiri bertumpu \\
\hline
\end{tabular}

\begin{tabular}{|l|l|lc|}
\hline & & $\begin{array}{l}\text { pada kedua } \\
\text { lurus }\end{array}$ & kaki \\
\hline $\begin{array}{l}\text { Berat } \\
\text { beban }\end{array}$ & 1 & $\begin{array}{l}\text { Berat beban lebih } \\
\text { kecil atau sama } \\
\text { dengan } 10 \mathrm{Kg} .\end{array}$ \\
\hline
\end{tabular}

7. Stasiun Pengemasan

a. Pekerja melakukan pengangkatan loyang untuk di antar ke pengemasan.

Tabel 12. OWAS Stasiun Pengemasan Postur 1

\begin{tabular}{|l|l|l|}
\hline \multicolumn{1}{|c|}{ SIKAP } & KODE & \multicolumn{1}{|c|}{ KETERANGAN } \\
\hline Punggung & 2 & $\begin{array}{l}\text { Bungkuk kedepan } \\
\text { atau kebelakang }\end{array}$ \\
\hline Lengan & 1 & $\begin{array}{l}\text { Kedua lengan berada } \\
\text { di bawah bahu }\end{array}$ \\
\hline Kaki & 6 & $\begin{array}{l}\text { Berlutut pada satu } \\
\text { atau kedua lutut }\end{array}$ \\
\hline $\begin{array}{l}\text { Berat } \\
\text { beban }\end{array}$ & 1 & $\begin{array}{l}\text { Berat beban lebih } \\
\text { kecil atau sama } \\
\text { dengan 10 Kg. }\end{array}$ \\
\hline
\end{tabular}

b. Pekerja melakukan aktivitas pengantaran loyang untuk di antar ke pengemasan.

Tabel 13. OWAS Stasiun pengemasan Postur 2

\begin{tabular}{|l|l|l|}
\hline \multicolumn{1}{|c|}{ SIKAP } & KODE & KETERANGAN \\
\hline Punggung & 1 & Lurus \\
\hline Lengan & 1 & $\begin{array}{l}\text { Kedua lengan berada } \\
\text { di bawah bahu }\end{array}$ \\
\hline Kaki & 7 & Berjalan \\
\hline $\begin{array}{l}\text { Berat } \\
\text { beban }\end{array}$ & 1 & $\begin{array}{l}\text { Berat beban lebih } \\
\text { kecil atau sama } \\
\text { dengan 10 kg. }\end{array}$ \\
\hline
\end{tabular}

\subsection{Aktivitas Pengadukan Tepung}

Dari tabel di atas menunjukkan angka (1), yang berarti bahwa kode 1121 dimana (1) postur punggu lurus, (1) postur tangan dimana kedua lengan berada di bawah bahu, (2) postur kaki berdiri bertumpu pada kedua kaki lurus dan (1) berat beban lebih kecil atau sama dengan $10 \mathrm{Kg}$. Dimana yang dilakukan pekerja termasuk dalam kategori 1 yaitu pada sikap kerja ini tidak ada masalah pada 
sistem muskuloskeletal (tidak berbahaya).

Sehingga tidak perlu ada perbaikan.

1. Aktivitas Pengangkatan Loyang

Tabel 14. Postur Kerja Usulan

Aktivitas Pengangkatan Loyang

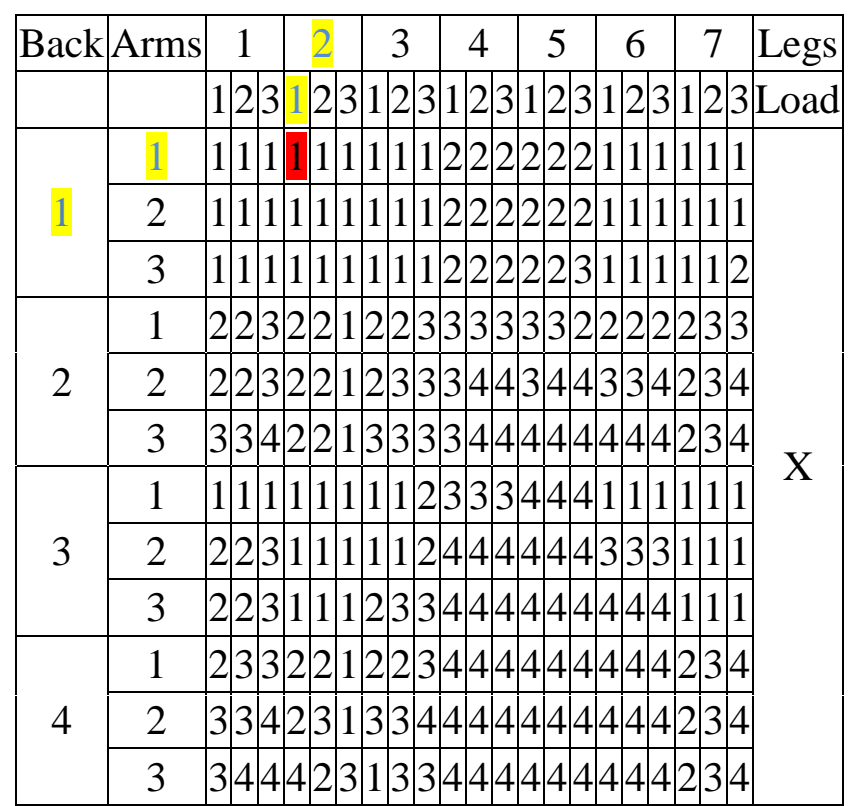

Dari tabel di atas menunjukkan angka (1), yang berarti bahwa kode 1121 dimana (1) postur punggu lurus, (1) postur tangan dimana kedua lengan berada di bawah bahu, (2) postur kaki berdiri bertumpu pada kedua kaki lurus dan (1) berat beban lebih kecil atau sama dengan $10 \mathrm{Kg}$. Dimana yang dilakukan pekerja termasuk dalam kategori 1 yaitu pada sikap kerja ini tidak ada masalah pada sistem muskuloskeletal (tidak berbahaya). Sehingga tidak perlu ada perbaikan.

2. Aktivitas Mengantar Loyang ke Stasiun Fermentasi

Tabel 15. Postur Kerja Usulan Postur Kerja Aktivitas Mengantar Loyang

\begin{tabular}{|c|c|c|c|c|c|c|c|c|c|}
\hline Back & Arms & 1 & 2 & 3 & 4 & 5 & 6 & 7 & Legs \\
\hline & & 123 & 23 & 123 & 123 & 123 & 12 & $\begin{array}{llll}3 & 1 & 2 & 3 \\
\end{array}$ & Load \\
\hline \multirow{3}{*}{1} & 1 & $\begin{array}{llll} & 1 & 1\end{array}$ & $\begin{array}{llll} & 1 & 1\end{array}$ & $\begin{array}{lll} & 1 & 1\end{array}$ & 222 & 222 & $\begin{array}{lll}1 & 1 \\
\end{array}$ & $\begin{array}{llll}1 & 1 & 1 & 1\end{array}$ & \multirow{5}{*}{ X } \\
\hline & 2 & $\begin{array}{lll}1 & 1 & 1 \\
\end{array}$ & $\begin{array}{llll}1 & 1 & 1 \\
\end{array}$ & $\begin{array}{llll}1 & 1 & 1\end{array}$ & 222 & 222 & & $\begin{array}{lllll}1 & 1 & 1 & 1 \\
\end{array}$ & \\
\hline & 3 & $\begin{array}{lll}1 & 1 & 1\end{array}$ & $\begin{array}{llll}1 & 1 & 1 \\
\end{array}$ & $\begin{array}{lll}1 & 1 & 1\end{array}$ & 222 & 223 & & $\begin{array}{lllll}1 & 1 & 1 & 2 \\
\end{array}$ & \\
\hline & 1 & $\begin{array}{llll}2 & 2 & 3\end{array}$ & 22 & 223 & 333 & $\begin{array}{lll}332 & \\
\end{array}$ & $2|2|$ & \begin{tabular}{|l|l|l|}
2 & 3 & 3
\end{tabular} & \\
\hline & 2 & $\begin{array}{lll}2 & 2 & 3\end{array}$ & $\begin{array}{lll}2 & 2 & 1\end{array}$ & $\begin{array}{ll}233 \\
\end{array}$ & 344 & 344 & \begin{tabular}{ll|}
33 \\
\end{tabular} & \begin{tabular}{l|l|l|l}
4 & 34
\end{tabular} & \\
\hline
\end{tabular}

\begin{tabular}{|c|c|c|}
\hline & 3 & 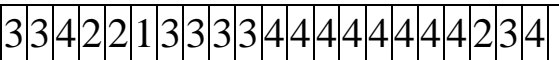 \\
\hline \multirow{3}{*}{3} & 1 & 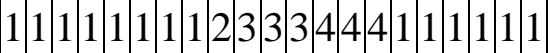 \\
\hline & 2 & 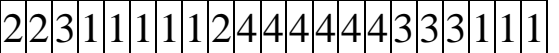 \\
\hline & 3 & 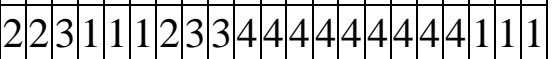 \\
\hline \multirow{3}{*}{4} & 1 & 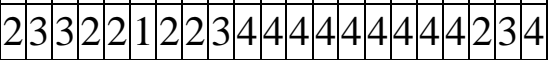 \\
\hline & 2 & 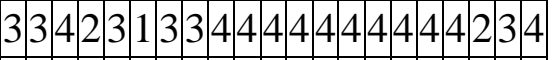 \\
\hline & 3 & 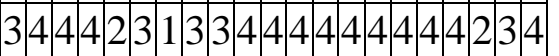 \\
\hline
\end{tabular}

Dari tabel di atas menunjukkan angka (2), yang berarti bahwa kode 1171 dimana (1) postur punggung lurus, (1) kedua lengan berada di bawah bahu, (7) postur kaki berjalan dan (1) berat beban lebih kecil atau sama dengan $10 \mathrm{Kg}$. Dimana yang dilakukan pekerja termasuk dalam kategori 2 yaitu Pada sikap ini berbahaya pada sistem musculoskeletal (postur kerja mengakibatkan pengaruh ketegangan yang signifikan). Sehingga tidak ada perlu perbaikan.

\section{Aktivitas peletakan loyang di fermentasi}

Tabel 16. Postur Kerja Usulan Aktivitas Peletakan Loyang di Fermentasi

\begin{tabular}{|c|c|c|c|c|c|c|c|c|c|c|}
\hline \multicolumn{2}{|c|}{ Back Arms } & \begin{tabular}{|l|l} 
& 1
\end{tabular} & 2 & 3 & 4 & 5 & 6 & & 7 & Legs \\
\hline & & \begin{tabular}{l|l|l}
1 & 2 & 3 \\
\end{tabular} & 123 & 12 & 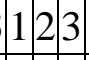 & 123 & & 31 & 23 & Load \\
\hline \multirow{3}{*}{1} & 1 & $\begin{array}{lll}1 & 1 & 1\end{array}$ & $\begin{array}{llll} & 1 & 1 \\
\end{array}$ & 11 & 222 & 222 & & 11 & 11 & \multirow{12}{*}{$\mathrm{X}$} \\
\hline & 2 & $\begin{array}{lll}1 & 1 & 1\end{array}$ & $\begin{array}{lll}1 & 1 & 1 \\
\end{array}$ & 11 & 222 & 222 & & 11 & 11 & \\
\hline & 3 & $\begin{array}{lll}1 & 1 & 1\end{array}$ & $\begin{array}{llll} & 1 & 1 & 1\end{array}$ & 11 & \begin{tabular}{l|l|l|}
2 & 2 & 2
\end{tabular} & 223 & & 11 & 12 & \\
\hline \multirow{3}{*}{2} & 1 & 223 & 221 & 22 & $\begin{array}{lll}3 & 3 & 3 \\
\end{array}$ & 332 & 22 & 22 & 33 & \\
\hline & 2 & 223 & $\begin{array}{lll}2 & 2 & 1\end{array}$ & 23 & 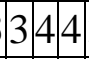 & 344 & 33 & 42 & 34 & \\
\hline & 3 & $\begin{array}{lll}3 & 3 & 4 \\
\end{array}$ & 221 & 33. & 344 & 444 & 44 & 42 & 34 & \\
\hline \multirow{3}{*}{3} & 1 & $\begin{array}{lll}1 & 1 & 1\end{array}$ & $\begin{array}{lll}1 & 1 & 1 \\
\end{array}$ & 11 & 333 & 444 & & 11 & 11 & \\
\hline & 2 & \begin{tabular}{l|l|l}
2 & 2 & 3 \\
\end{tabular} & $\begin{array}{lll}1 & 1 & 1 \\
1\end{array}$ & 11 & 444 & $\begin{array}{lll}44 & 4 \\
\end{array}$ & & $\begin{array}{ll}3 & 1 \\
\end{array}$ & 11 & \\
\hline & 3 & $2 \sqrt{3}$ & $\begin{array}{lll}1 & 1 & 1\end{array}$ & 23 & 444 & 444 & 44 & 41 & 11 & \\
\hline \multirow{3}{*}{4} & 1 & 233 & 221 & 22 & 444 & 444 & 44 & 42 & 34 & \\
\hline & 2 & 334 & 231 & 33. & 444 & 444 & 44 & 42 & 34 & \\
\hline & 3 & $\begin{array}{lll}3 & 4\end{array}$ & 423 & 13 & $\begin{array}{lll}4 & 4 \\
\end{array}$ & 444 & 44 & 42 & 34 & \\
\hline
\end{tabular}

Dari tabel di atas menunjukkan angka (1), yang berarti bahwa kode 1121 dimana (1) postur punggu lurus, (1) postur tangan dimana kedua lengan berada di bawah bahu, (2) postur kaki berdiri bertumpu pada kedua kaki lurus dan (1) 
berat beban lebih kecil atau sama dengan $10 \mathrm{Kg}$. Dimana yang dilakukan pekerja termasuk dalam kategori 1 yaitu pada sikap kerja ini tidak ada masalah pada sistem muskuloskeletal (tidak berbahaya). Sehingga tidak perlu ada perbaikan.

4. Aktivitas Mengangkat Loyang ke Oven

Tabel 17. Postur Kerja Usulan

Mengangkat Loyang ke Oven

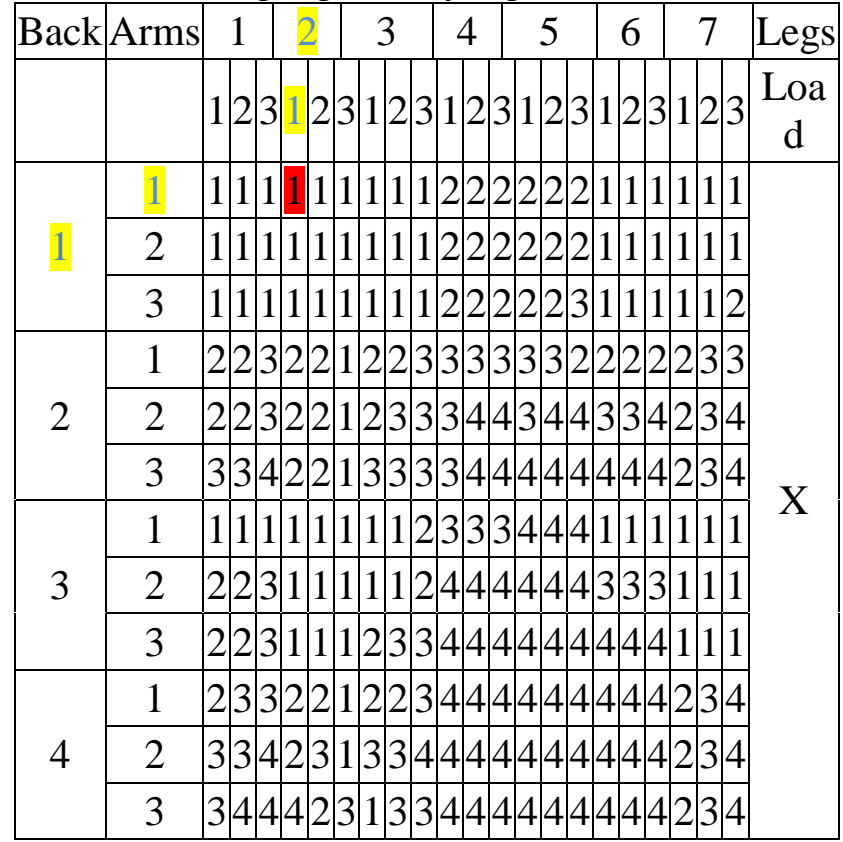

Dari tabel di atas menunjukkan angka (1), yang berarti bahwa kode 1121 dimana (1) postur punggu lurus, (1) postur tangan dimana kedua lengan berada di bawah bahu, (2) postur kaki berdiri bertumpu pada kedua kaki lurus dan (1) berat beban lebih kecil atau sama dengan $10 \mathrm{Kg}$. Dimana yang dilakukan pekerja termasuk dalam kategori 1 yaitu pada sikap kerja ini tidak ada masalah pada sistem muskuloskeletal (tidak berbahaya). Sehingga tidak perlu ada perbaikan.

\section{Aktivitas Pemanggangan di Oven}

Tabel 18. Postur Kerja Usulan Aktivitas Pemanggangan

\begin{tabular}{|l|l|l|l|l|l|l|l|l|}
\hline Back Arms & 1 & 2 & 3 & 4 & 5 & 6 & 7 & Legs \\
\hline
\end{tabular}

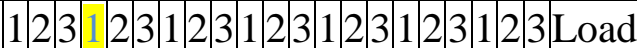

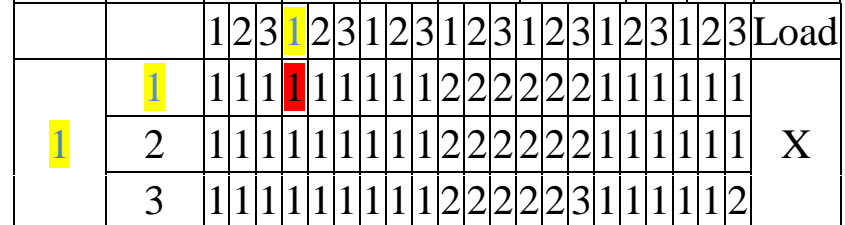

\begin{tabular}{|c|c|c|}
\hline \multirow{3}{*}{2} & & 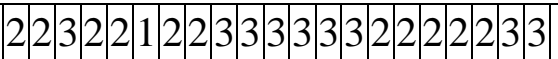 \\
\hline & 2 & 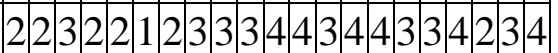 \\
\hline & 3 & 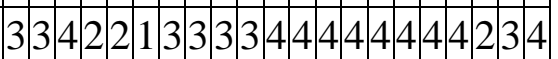 \\
\hline \multirow{3}{*}{3} & 1 & 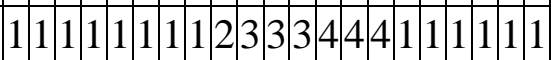 \\
\hline & 2 & 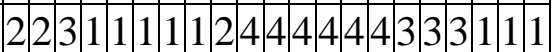 \\
\hline & 3 & 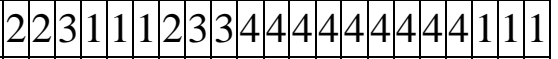 \\
\hline \multirow{3}{*}{4} & 1 & 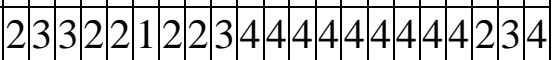 \\
\hline & 2 & 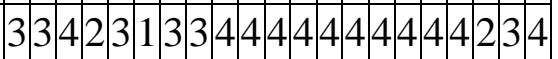 \\
\hline & 3 & 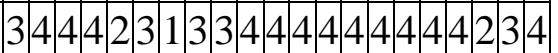 \\
\hline
\end{tabular}

Dari tabel di atas menunjukkan angka (1), yang berarti bahwa kode 1121 dimana (1) postur punggu lurus, (1) postur tangan dimana kedua lengan berada di bawah bahu, (2) postur kaki berdiri bertumpu pada kedua kaki lurus dan (1) berat beban lebih kecil atau sama dengan $10 \mathrm{Kg}$. Dimana yang dilakukan pekerja termasuk dalam kategori 1 yaitu pada sikap kerja ini tidak ada masalah pada sistem muskuloskeletal (tidak berbahaya). Sehingga tidak perlu ada perbaikan.

6. Aktivitas pengangkatan loyang ke stasiun pengemasan

Tabel 19. Postur usulan Aktivitas Pengangkatan Loyang

\begin{tabular}{|c|c|c|c|c|c|c|c|c|c|c|}
\hline Back & Arms & 1 & 2 & 3 & 4 & 5 & 6 & & 7 & Legs \\
\hline & & \begin{tabular}{l|l|l|l|l|l|l|} 
& \\
\end{tabular} & \begin{tabular}{l|l|l}
1 & 23 \\
\end{tabular} & 123 & 123 & \begin{tabular}{l|l|l|l|}
3 & 1 \\
\end{tabular} & $\mid \begin{array}{lll}3 & 1 & 2\end{array}$ & & 123 & Load \\
\hline \multirow{3}{*}{1} & 1 & $\begin{array}{lll}1 & 1 & 1\end{array}$ & 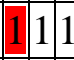 & $\begin{array}{llllll} & 1 & 1\end{array}$ & 222 & 222 & \begin{tabular}{ll|l}
2 & 1 & 1
\end{tabular} & 11 & \begin{tabular}{l|l|l}
1 & 1 & 1 \\
\end{tabular} & \multirow{12}{*}{ X } \\
\hline & 2 & $\begin{array}{llll}1 & 1 & 1\end{array}$ & \begin{tabular}{l|l|l}
1 & 1 & 1 \\
\end{tabular} & $\begin{array}{lll}1 & 1 & 1\end{array}$ & 222 & 222 & $\begin{array}{lll}2 & 1 & 1\end{array}$ & $\begin{array}{lll}1 & 1 \\
\end{array}$ & \begin{tabular}{ll|l}
1 & 1 & 1 \\
\end{tabular} & \\
\hline & 3 & $\begin{array}{lll}1 & 1 & 1\end{array}$ & $\begin{array}{lll} & 1\end{array}$ & $\begin{array}{lll}1 & 1 & 1\end{array}$ & 222 & 222 & $\begin{array}{lll}3 & 1\end{array}$ & $1 \mid 1$ & \begin{tabular}{l|l|l}
1 & 1 & 2
\end{tabular} & \\
\hline \multirow{3}{*}{2} & 1 & 223 & $\begin{array}{lll}2 & 2 & 1 \\
\end{array}$ & 223 & 333 & 333 & 222 & 22 & \begin{tabular}{l|l|l|}
2 & 3 & 3 \\
\end{tabular} & \\
\hline & 2 & \begin{tabular}{l|l|l|l|l|l|l|}
2 & 3 \\
\end{tabular} & \begin{tabular}{l|l|l|l|}
2 & 2 & 1 \\
\end{tabular} & 233 & 34 & 434 & 433 & 34 & \begin{tabular}{l|l|l}
2 & 3 & 4 \\
\end{tabular} & \\
\hline & 3 & $\begin{array}{llll}3 & 3 & 4 \\
\end{array}$ & \begin{tabular}{|l|l|l|l|}
2 & 2 & 1 \\
\end{tabular} & 33 & 34 & 444 & 44 & & \begin{tabular}{l|l|l}
2 & 3 & 4 \\
\end{tabular} & \\
\hline \multirow{3}{*}{3} & 1 & $\begin{array}{llll}1 & 1 & 1 \\
\end{array}$ & \begin{tabular}{|l|l|l|l|l}
1 & 1 & 1 \\
\end{tabular} & $\begin{array}{lll}1 & 1 & 12\end{array}$ & 333 & 344 & $\begin{array}{lll}4 & 1 & 1\end{array}$ & 11 & \begin{tabular}{l|l|l}
1 & 1 & 1
\end{tabular} & \\
\hline & 2 & \begin{tabular}{l|l|l|l|}
2 & 2 & 3
\end{tabular} & 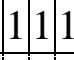 & 1112 & $4 \mid 4$ & $4|4|$ & +433 & 33 & $1|1| 1$ & \\
\hline & 3 & 223 & $\begin{array}{llll} & 1 & 1 & 1 \\
\end{array}$ & 233 & 44 & 444 & 444 & 44 & \begin{tabular}{l|l|l}
1 & 1 & 1 \\
\end{tabular} & \\
\hline \multirow{3}{*}{4} & 1 & $\begin{array}{lll}2 & 3 & 3 \\
\end{array}$ & \begin{tabular}{|l|l|l}
2 & 2 & 1 \\
\end{tabular} & 223 & 44 & 444 & $4 \mid 44$ & 44 & \begin{tabular}{l|l|l}
2 & 3 & 4
\end{tabular} & \\
\hline & 2 & $\begin{array}{lll}3 & 3 & 4 \\
\end{array}$ & \begin{tabular}{|l|l|l|}
2 & 3 & 1 \\
\end{tabular} & 334 & 44 & 444 & 444 & 44 & \begin{tabular}{l|l|l|}
2 & 3 & 4 \\
\end{tabular} & \\
\hline & 3 & 344 & 423 & 133 & 44 & $4 \mid 44$ & $4|4| 4$ & $4 \mid 4$ & \begin{tabular}{l|l|l|}
2 & 3 & 4
\end{tabular} & \\
\hline
\end{tabular}

Dari tabel 4.44 di atas menunjukkan angka (1), yang berarti bahwa kode 1121 dimana (1) postur punggu lurus, (1) postur tangan dimana 
kedua lengan berada di bawah bahu, (2) postur kaki berdiri bertumpu pada kedua kaki lurus dan (1) berat beban lebih kecil atau sama dengan $10 \mathrm{Kg}$. Dimana yang dilakukan pekerja termasuk dalam kategori 1 yaitu pada sikap kerja ini tidak ada masalah pada sistem muskuloskeletal (tidak berbahaya). Sehingga tidak perlu ada perbaikan.

\section{KESIMPULAN}

Hasil penelitian mengenai analisis postur kerja para pekerja Manual Material Handling pada industri kecil pembuatan roti di Pabrik Roti Cimpago Putih dapat disimpulkan sebagai berikut :

Perbaikan postur kerja dengan metode OWAS, yaitu postur kerja punggung dan pinggul diusahakan segaris ketika melakukan aktivitas MMH. Sehingga dapat mengurangi keluhan nyeri pada bagian punggung bawah (low back pain). Usulan perbaikan postur kerja, teridentifikasi sebanyak

a. 4 postur kerja dalam kategori 2 dalam arti berbahaya pada sistem musculoskeletal, perlu perbaikan dimasa yang akan datang.

b. Serta 4 postur kerja yang tergolong dalam kategori 1, yang berarti tidak berbahaya pada sistem musculoskeletal, tidak perlu perbaikan.

c. Dan terdapat 3 postur kerja yang tergolong katagori 3 dimana Pada sikap ini berbahaya pada sistem musculoskeletal (postur kerja mengakibatkan pengaruh ketegangan yang sangat signifikan). Perlu perbaikan segera mungkin.

\section{DAFTAR KEPUSTAKAAN}

Andriyano. Analisis Konsumsi Energi dan Identifikasi Kondisi Postur Kerja Pada Proses Perontok Padi Menggunakan Metode OWAS, Universitas Muhammadiyah Surakarta, 2008.
Cross, Nigel. Engineering Design Methods Strategies for Product Design, Edisi 2, United Kingdom,1994.

Ervil Riko. Buku Panduan Penulisan Dan Ujian Skripsi, STTIND Padang, Padang, 2014.

Eko Nurmianto, Ergonomi Konsep Dasar dan Aplikasinya, Prima Printing. Surabaya 2008.

Iftikar Z. Sutalaksana, dkk, Teknik Perancangan Sistem Kerja, ITB, Bandung, 2008.

Irma Ade. Skripsi Usulan Perbaikan Postur Kerja Operator Dengan Mengunakan Metode Ovako Working Posture Analisis Syetem (OWAS) di Terminal Kargo Polonia, Universitas Sumatera Utara, Medan, 2010.

McCormick, E.J and M.S. Sanders. Human Factor in Engineering and Design, New York, 1994.

Madyana. Analisa Perancangan Kerja dan Ergonomi, Universitas Atmajaya Yogyakarta press, Yogyakarta, 1996.

Sutalaksana. Teknik Perancangan Sistem Kerja. Laboratorium Tata Cara Kerja dan Ergonomi Dept. Teknik IndustriITB, Bandung, 2006.

Sunarso. Skripsi Perancangan Troli Sebagai Alat Bantu Angkut Galon Air Mineral Dengan Pendekatan Anthropometri di Agen Air Mineral Asli Sukoharjo, Universitas Sebelas Maret, Surakarta, 2010.

Widodo. Perancangan dan Pengembangan Produk, UI Press, Yogyakarta, 2006. 